DOI: 10.20472/BMC.2018.008.022

\author{
EMEKA OKEREKE \\ University of Port Harcourt, Nigeria \\ UFUOMA OFIEROHOR \\ University of Port Harcourt, Nigeria
}

\title{
HEALTH FINANCE AND ECONOMIC GROWTH IN NIGERIA.
}

\begin{abstract}
:
This study, health finance and economic growth in Nigeria over a period of 1990-2016, aims at examining the effect of health financing on economic growth in Nigeria. It utilized secondary data, sourced from the Statistical Bulletin of Central Bank of Nigeria . Data on Gross Domestic Product (GDP), Capital Expenditure on Health (CXHE), Human Health \& Social Services Output Investment (HHSS) and Recurrent expenditure on health (RXHD) were analysed using econometric package, Eview, to test for stationarity; Johansson cointegration test, and Error Correction Mechanism (ECM) were employed. It was found that a long run significant positive relationship exist between Capital Expenditure on Health (CXHE) and gross domestic product (GDP) with very marginal contribution, significant positive relationship between Human Health \& Social Services Output Investment (HHSS) and gross domestic product (GDP), insignificant negative relationship between Recurrent expenditure on health (RXHD) and gross domestic product (GDP) in Nigeria. There is clear evidence of inequality in the access to health care services and low income characteristics of the country in view of the high level of Out-of-Pocket Health Expenditure of $77.7 \%, 77.5 \%$ and $72.2 \%$ in 2005, 2010 and 2015 respectively. It therefore recommends that Nigerian government should, as a matter of priority, increase budgetary allocation to the health sector by $40 \%$ yearly incremental allocation based on the current (2017) provision of $4.16 \%$. They should also give deliberate attention to developing health infrastructures and providing quality health services. Investment in human capital and public health should be made a priority as, it not only increases labour productivity, but also generates greater income and economic growth.
\end{abstract}

\section{Keywords:}

Health Finance, Gross Domestic Product, Capital Expenditure on Health, Human Health \& Social services Output Investment, Out-of-pocket health expenditure.

JEL Classification: E62 


\subsection{Introduction}

Health is wealth is a commonly enjoyed slogan. Obviously because ones state of health determines his productivity. This is in line with Jakovljevic and Getzen (2016) when they noted "There is a general saying that health is wealth; when the health status of a people in a society is good, the citizens will have more time and more money to invest in production of goods and services rather than spending such monies in hospital" This establishes a strong relationship between health of citizens (human capital) and productivity, which translates into increased national output. Thus, provision of health facilities and their access are keys to healthy citizens, who represents the human capital as input in the production process. Financing these facilities and the entire health sector is germane to good health, viable human capital and improved productivity at individual and national levels. This establishes a relationship between health finance, human capital and national output. According to Loto (2011) a host of literature has been done on the relationship between economic growth and human capital. The relationship between human capital in developing an economy has been recorded. Human capital development encompasses health, education, migration and other individual productivity investment. Health finance which has to do with the planning, sourcing, organization and utilization of funds to finance health system is so paramount to the growth of a society (Olakunde, 2012).

The health finance system status in Nigeria is low when compared with most countries of the world. Nigeria's Total Health Expenditure as \% of GDP was 3.6\% in 2015 and ranked 165 out of 187. (World Bank Open Data). No wonder there is dominance of HIV/AIDS, diabetes, malaria, high infant and mortality rates and are the key incarnates of Nigeria's health status. This calls for greater emphasis on health finance in Nigeria as a critical factor for economic growth.

Historically, the low level of health finance in Nigeria attracted the intervention of health insurance in Nigeria in 1962 leading to the enactment of the National Health Insurance Scheme (NHIS) Act 35 of 1999. This strategic development resulted in the gradual increase in coverage from less than 150,000 lives in 2004 to about 5 million (3\% of the population) in 2014 (Bhatnagar and George, 2016). Families and public sector workers are what national health insurance scheme currently covers. It is a social security arrangement with a comprehensive benefit package that provides financial security to the citizens against unforeseen ill health. The Scheme comprises programmes that cover formal sector workers, informal sector workers and the vulnerable groups. According to Onisanwa (2014) Nigeria is among the developing nations with poor health outcomes and its attendant problems. The health status of Nigerians is still considerably low and exists below that of some countries in West Africa, as noted earlier. Low life expectancy at birth, high infant and maternal mortality rates, malaria and tuberculosis afflictions are some of 
the characteristic features of the Nigeria's health status. Life expectancy at birth in Nigeria was estimated at only 48 in 2007, 53.4 in 2016 compared with 56, 62.7 respectively in Ghana. This is complemented by the high numbers of women who die of complications during pregnancy or childbirth. Empirical evidence shown by Oni (2014) in his work on the impact of health expenditure on economic growth in Nigeria using multiple regression analysis. He found that gross capital formation, total health expenditures and the labour force productivity are important determinants of economic growth in Nigeria while life expectancy rate has negative impact on growth for the period covered by the study. Based on this, the following policy measures were suggested, among others, that government should encourage savings and investments in the economy, increase expenditures on health provisions, induce the level of labour productivity and place priority on the issues of security to lives and properties in Nigeria.

Generally, the association existent between Health finance and economic growth has protracted various attention and controversies in the International health works and writings, with repute to a theoretical association between health finance and gross domestic product. As some researchers like Kurt (2015), Onisanwa (2014) and Oni (2014) give credence to the positive effect of health finance on economic growth, others contradict these positions pointing out that health finance is not a major factor affecting economic growth rather it is technology and other factors that led to economic growth (Karim, 2016). Various econometric research and literatures have strained to ascertain the association and causal relationship between health finance and economic growth and we are aligning to this league.

Given the above background, the main objective of this study is to examine the effect of health finance on economic growth in Nigeria. Specifically, we focused on evaluating health finance in relation to capital expenditure, human health \& social services output investment and recurrent expenditure in Nigeria.

To put the paper into proper perceptive, it is divided into 5 sections. Section 1 introduced the study while section 2 reviewed it. Methodology is captured in chapter 4 and chapter 4 provided the analyses of data. Discussion, conclusion and recommendations were treated in section 5 . 


\section{Literature Review}

\subsection{Conceptual/Theoretical Foundations}

The strategic search for funds by the government of a society is anchored on the drive to make rewarding investment in human capital. According to Todaro and Smith (2009) investment in education, health, and other capacities help improve the productive performance of a society. One of best agents of economic performance is investment in health. Oni (2014), clearly stated that a nation that is healthy is a wealthy nation. Health lead growth hypothesis states that when investment is made on health a positive implication will be on the economy. Mushkin (1992), clearly states that health care spending helps foster economic growth. When a people are healthy more money will be made on investment rather than paying hospital bills, therefore this makes health finance so paramount to the growth of a society. Other theories of economic growth caved out a nuxus between health and economic growth. Solow and Swan wrote on the importance of capital formation on economic growth. It was clearly stated that health finance is a key driver of economic growth. Saima, et al. (2012), clearly stated that the major factor of human capital development is education and health and this will in turn lead to economic development. This made an impetus of Fagerlind and Saha (1997), Dauda (2010), and Olayemi (2012) wherein they made justification that health and education finance are key factors of economic growth.

Theoretically, two baseline theories are appropriately reviewed for this study. They are Wagner theory of increasing state activity and the Ragnar Nurske balanced growth theory.

In the late 19th century Wagner, developed the Law (Theory) of Increasing State Activity which states that "as the economy develops over time, the activities and functions of the government increase". This means that increases in government activities overtime is accompanied by increased public expenditure leading to economic growth/development. This invariably connotes that in a developing nation like Nigeria, Government would fare better should they delve financial related activities into other sectors including the health sector, which determines the speed and stability of other sectors of the economy. In this line, expenditure towards this sector should be bolstered. And in the private sector, further incentives should be kept in place to ensure that increasing activity in this sector is apportioned to the right activities to which health is number one party to (Peacock, 2004).

The balanced growth theory as proposed by Nurske (1959), supports the need for government and related institutions to make the right investment on a simultaneous basis, and a crucial investment comes in the form of Human capital. The health sector 
would benefit from such investments which would ripple into other sectors proportionately. And in which light, the private sector is also not excluded (Torvik, 2002).

\subsection{Empirical evidence}

Karim (2016) evaluates the economic growth nexus of health expenditure in Nigeria spanning a period of 1985-2009 utilizing the auto regressive distributive Lag (ARDL) model and cointegration test. The studied discovered that health expenditure does not significantly influence economic growth.

Idowu (2014) evaluates the impact of health on economic growth in Nigeria spanning a period of 1995-2009 utilizing cointegration and granger causality techniques using quarterly time series data. The study unveiled that health indicators have long run influence on economic growth.

Akintunde (2013) researched on the Effect of Health Investment on Economic Growth in Nigeria spanning from 1977-2010 using vector error correction model. The study unveiled that there is a positive relationship between health expenditure and economic growth in Nigeria.

Musibau (2014) Did a research on the relationship between health and economic growth in Nigeria spanning from 1970-2008 utilizing granger causality test employing annual data. The study discovered a positive relationship between improved public health and economic growth.

Oni (2014) researched on Growth Impact of Health Expenditure in Nigeria spanning from 1970-2010 utilizing mulpiple regression analysis. The study discovered that total health expenditure is positively related to economic growth.

Mehrara and Musai (2011) did a research on the effect of health expenditure and growth of an economy from 1970-2007 in Iran. A negative result was found between health finance and economic growth using autoregressive distribution lag approach.

Adediran (2014) evaluated Public Investment in Human Capital and Economic Growth in Nigeria: Analysis on Regime Shifts using Johansen's cointegration technique, augumented dickey fuller and parsimonious error correction procedure spanning from 1961-2012. Found that government expenditure on health and education has a positive influence on economic growth. In light of conflicting studies it becomes important that a research of this nature be done in order to underscore the prevailing situations in Nigeria especially in view of very low budgetary allocation of $3.5 \%$ compared to the AU Abuja declaration of $15 \%$. 


\section{Methodology}

This section presents the data used, as shown in Table 1, Appendix 1. It is time series secondary data sourced from Central Bank of Nigeria (CBN) Statistical Bulletin, Annual Review and World Bank Open Data. The period covered spans from 1990 to 2016. This section also provides for econometric tools employed. Some of them are as explained below.

\section{Unit Root Test}

The stationarity of series utilized for this research was determined with the estimation of unit root. Dickey Fuller (DF) unit root test might be estimated from the following forms of equations. Based on the following regression equation:

$\Delta Y_{t}=\alpha+\beta T+\delta Y_{t-1}+Y_{i} \Delta Y_{t-i}+\varepsilon t$

\section{Hypothesis:}

"HO : $\square>0$ (there is unit root in the series).

$H 1: \square \square<0$ (the series are stationary)

Decision rule: Reject $H_{0}$ if test statistic is less than critical values, otherwise do not reject." (Haris and Sollis, 2004; Elliott et al.,1996).

\section{Co-integration}

The research applied Johansen Co-integration Rank Test, which is used in ascertaining and determining the co-integration rank of variables. As a prerequisite or condition to model with Vector Error Correction Model, there must exist a co-integration relationship (Adbullahi et al, 2012). Cointegration test is utilized "to ascertain the presence of potential long run equilibrium association between two variables" (Awe, 2012) and expressed as:

$Y t=\mu+T Y t-1+\varepsilon t$

$\Delta x t=k X-1 i=1 \Gamma i \Delta x t-i+\Pi x t-1+\mu 0+\Psi D t+\varepsilon t$.

Decision rule: "Accept $H_{0}$ : (there is no substantial cointegration relationship) if t- statistic is greater than asymptotic critical - value or if the $p$ - value is below the significance level, otherwise accept $H 1$ : (there is substantial cointegration relationship) if test statistic is less than the asymptotic critical values or if the $p$ - value is greater than the level of significance". 


\section{Parsimonious Dynamic Error Correction Model}

This seeks to correct the error in the model. Error Correction Models (ECMs) entails a series of longitudinal models which seeks to appraise the amendment speed at which a criterion variable returns to equilibrium after a change in a Predictor variable.

Estimation of ECMs of the form:

$$
\text { et } 1+v t \square
$$

(Banerjee et al. 1993; Hamilton, 1994; Johansen 1995)

ECMs are useful for appraising the long and short term influences of one longitudinal on another. This research will utilize vector Error correction model.

\section{Model specification}

This study formulates its model in a functional and mathematical forms respectively as

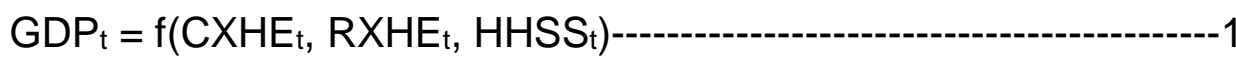

$\left.\mathrm{GDP}_{t}=\beta_{0}+\beta_{1} \mathrm{CXHE}_{t}+\beta_{2} \mathrm{RXHE}_{t}+\beta_{3} \mathrm{HHSS}_{\mathrm{t}}\right)---\cdot-\cdot-\cdot-\cdot-\cdot-\cdot---2$

Econometrically, the model is presented as follows

$\left.\mathrm{GDP}_{t}=\beta_{0}+\beta_{1} \mathrm{CXHE}_{t}+\beta_{2} \mathrm{RXHE}_{t}+\beta_{3} \mathrm{HHSS}_{t}+\mu_{t}\right)--\cdot-\cdot-\cdots$

Where:

GDP $=$ Gross domestic product

$\mathrm{CXHE}=\quad$ Capital Expenditure on Health

$\mathrm{RXHE}=\quad$ Recurrent expenditure on health

HHSS $=\quad$ Human Health \& Social Services Output Investment 
$\mu_{\mathrm{t}} \quad=\quad$ Error term

$\beta 0=$ Constant/Intercept

$\beta 1-\beta 3=\quad$ Coefficient or Slope

\section{Operational measure of variables}

Economic growth (Gross Domestic Product \{GDP\}): This is captured as the annual aggregate output of an economy over the sample period. This is affected by the predictor variables positively or negatively.

Capital Expenditure on Health (CXHE): Payments for acquisition of fixed capital assets, land or intangible assets for health related purposes. It is expected to enhance economic growth.

Recurrent Expenditure on Health (RXHE): Recurrent expenditure on health is expenditure, which does not result in the creation or acquisition of fixed assets (new or second-hand). It consists mainly of expenditure on wages, salaries and supplements, purchases of goods and services and consumption of fixed capital. This is not expected to have positive effect on GDP.

Human Health \& Social Services Output Investment (HHSS): The investments made by the health sector in Nigeria. This will have positive effect on gross domestic product.

\section{Data Analysis and Presentation of Estimation Results}

Data for the study are analyzed accordingly and presented as estimation results.

\section{1: Presentation of Stationarity (Unit Root) Tests Result}

The unit root test is carried out using Augmented Dickey Fuller (ADF) test to evaluate the stationarity of the variables employed for the research. The result of the unit root test is presented in Table 2 below. 
Table 2. Result of Stationarity (Unit Root) Tests:

\begin{tabular}{|c|c|c|c|c|c|c|}
\hline \multirow[t]{2}{*}{ Variable } & \multirow{2}{*}{$\begin{array}{c}\text { ADF t- } \\
\text { statistics }\end{array}$} & \multicolumn{3}{|c|}{ Critical Value 5\% } & \multirow{2}{*}{$\begin{array}{l}\text { Order of } \\
\text { Integration }\end{array}$} & \multirow{2}{*}{ Prob. } \\
\hline & & $1 \%$ & $5 \%$ & $10 \%$ & & \\
\hline D(LOGGDP) & -4.099198 & -4.440739 & -3.632896 & -3.254671 & $\mathrm{I}(1)$ & 0.0020 \\
\hline D(LOGHHSS) & -5.396439 & -4.394309 & -3.612199 & -3.243079 & $\mathrm{I}(1)$ & 0.0011 \\
\hline D(LOGCXHE) & -4.427245 & -4.374307 & -3.603202 & -3.238054 & $\mathrm{I}(1)$ & 0.0004 \\
\hline D(LOGRXHE) & -5.517174 & -4.67895 & -3.644963 & -3.261452 & $\mathrm{I}(1)$ & 0.0012 \\
\hline
\end{tabular}

Using both $1 \%$ and $5 \%$ Substantial Level.

Source: Eview 8 Output (Authors' Computation and Compilation)

Note: D(LOGGDP), D(LOGHHSS), D(LOGCXHE) and D(LOGRXHE) are differenced value of Gross Domestic Product (GDP), Human Health \& Social Services Output Investment (HHSS), Capital Expenditure on Health(CXHE) and Recurrent Health Expenditure (RXHE) respectively over the research period.

The table above displays that the absolute ADF statistic values are higher than those of Mackinnon test Critical values at all levels and the accompanying probability estimates are all less than 0.05 , the preferred significance level therefore, acceptable. The result of the unit root output shows that all employed variables are integrated at order 1(1).

\subsection{Presentation of Johansen Co-integration Test Results:}

The results of Johansen's cointegration tests for all the longitudinal variables of this research are presented in Table 3 below: 
Table 3. Result of Johansen Unrestricted Co-integration Rank Test (Trace)

\begin{tabular}{|c|c|c|c|c|c|c|}
\hline Obs & Series & $\begin{array}{l}\text { Hypothesized } \\
\text { No. of CE(s) }\end{array}$ & Eigenvalue & $\begin{array}{l}\text { Trace } \\
\text { Statistic }\end{array}$ & $\begin{array}{l}\text { P } 0.05 \\
\text { Critical } \\
\text { Value }\end{array}$ & Prob. ${ }^{* *}$ \\
\hline \multirow[t]{4}{*}{26} & \multirow{3}{*}{$\begin{array}{l}\mathrm{D}(\mathrm{LOGCXHE}) \\
\mathrm{D}(\mathrm{LOGHHSS})\end{array}$} & None * & 0.515854 & 49.91983 & 47.85613 & 0.0316 \\
\hline & & At most $1^{*}$ & 0.411868 & 31.78562 & 29.79707 & 0.0291 \\
\hline & & At most $2^{*}$ & 0.355002 & 18.51553 & 15.49471 & 0.0170 \\
\hline & $\mathrm{D}(\mathrm{LOGRXHE})$ & At most $3^{*}$ & 0.260745 & 7.552809 & 3.841466 & 0.0060 \\
\hline
\end{tabular}

Trace test indicates 4 cointegrating eqn(s) at the 0.05 level

* denotes rejection of the hypothesis at the 0.05 level

**MacKinnon-Haug-Michelis (1999) p-values

Source: Eview 9 Output (Authors' Computation)

From the above table, the Trace statistic is greater than the Critical Values three in three equations. Thus, the co-integration results reported reveals the rejection of the null hypothesis of no existing co integration. The test output shows a co integrating association among the criterion variable and the predictor variables. It can thus be concluded that there exist a substantial long-run association between Criterion variable, Gross Domestic Product (GDP) and the Predictor variables namely Human Health \& Social Services Output Investment (HHSS), Capital Expenditure on Health (CXHE) and Recurrent Health Expenditure (RXHE).

However, the authors acknowledge that a shift from this association is possible due to changes in employed variables within the short-run. Therefore, we adopted the Error Correction Estimates (ECE) to examine and correct any short run changes in the variables under investigation. Thus, ECE is specified to show the short-run changes in the variables while preserving the long-run relationship. 


\section{CUSUN TEST OF MODEL STABILITY}

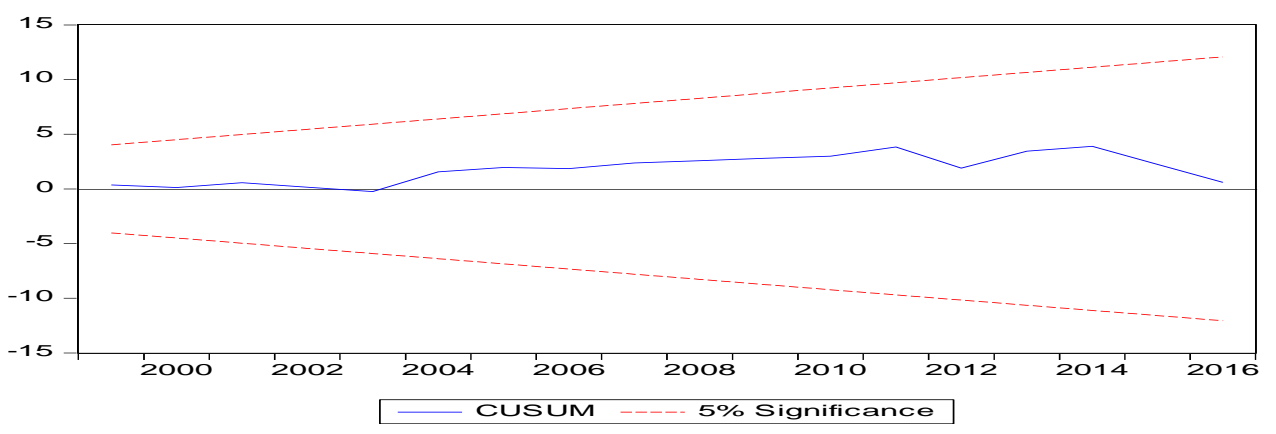

Fig. 1: Model Stability Test result

The cusum test is a model stability test. A stable model is good model. From our Figure 1 above, the blue line falls within the two read lines, we therefore conclude that the model is stable.

\section{3: Presentation of Estimation Results}

\section{Error Correction Model (ECM)}

\section{Table 4: MODEL 1}

Dependent Variable: D(LOGHHSS)

Method: Least Squares

Date: 06/24/18 Time: 08:41

Sample (adjusted): 19922016

Included observations: 25 after adjustments

\begin{tabular}{crrrr}
\hline \hline Variable & Coefficient & Std. Error & t-Statistic & Prob. \\
\hline \hline D(LOGHHSS(-1)) & 0.608811 & 0.149782 & 4.064650 & 0.0007 \\
D(LOGCXHE) & -0.003978 & 0.013238 & -0.300484 & 0.7673 \\
D(LOGCXHE(-1)) & 0.032681 & 0.013799 & 2.368416 & 0.0293 \\
D(LOGRXHE) & -0.012792 & 0.008830 & -1.448582 & 0.1647 \\
D(LOGRXHE(-1)) & -0.010481 & 0.008592 & -1.219862 & 0.2383 \\
ECM(-1) & 0.256000 & 0.090265 & 2.836109 & 0.0110 \\
C & 0.020919 & 0.010715 & 1.952286 & 0.0666 \\
\hline \hline R-squared & 0.722060 & \multicolumn{2}{c}{ Mean dependent var } & 0.050267 \\
Adjusted R-squared & 0.629414 & S.D. dependent var & 0.042934
\end{tabular}




$\begin{array}{lclr}\text { S.E. of regression } & 0.026137 & \text { Akaike info criterion } & 4.219471 \\ \text { Sum squared resid } & 0.012296 & \text { Schwarz criterion } & 3.878186 \\ & & & - \\ \text { Log likelihood } & 59.74339 & \text { Hannan-Quinn criter. } & 4.124813 \\ \text { F-statistic } & 7.793706 & \text { Durbin-Watson stat } & 1.973303 \\ \text { Prob(F-statistic) } & 0.000306 & & \\ \text { Source: E-view 9 Output (Authors' Computation) }\end{array}$

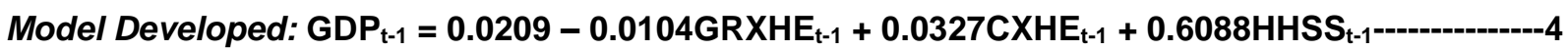

The ECM estimation output (Table 4) reveals that the predictor variables jointly account for about 72.20 percentage shocks in Gross Domestic Product, criterion variable. The Durbin-Watson statistics (1.97) is within the acceptable range and shows no presence of auto correlation. The absolute value of the coefficient of the Error Ccorrection Term indicates that about $25.60 \%$ of the disequilibrium in the level of Gross Domestic Product is offset by short run amendment in each year. The associated Prob ( F-Statistic) value of 0.000306 is statistically substantial at the $5 \%(0.05)$ significance level, which confirms a good line of fit. The estimation output also displays that the predictor variable value of GRXHE is not statistically substantial in explaining variability in Gross Domestic Product (GDP) but CXHE and HHSS are statistically significant in Nigeria at $5 \%$ level of significance. The lag values of the ECM result shows that the independent variable, GRXHE is negatively related to the dependent variable but Capital expenditure and Human Health \& Social Services Output Investment are positively related. It therefore means that recurrent expenditure on health led to a decrease in Gross Domestic Product in Nigeria while Capital expenditure and Human Health \& Social Services Output Investment increased it.

\section{Discussion, Recommendations and Conclusion}

\subsection{Discussion}

The findings are mixed and other researchers are aligning to them. The study found a positive significant relationship between Capital Expenditure on Health (CXHE), Human Health \& Social Services Output Investment (HHSS) and economic growth in Nigeria. This is supported by Musibau (2014) and Oni (2014) who found that total health expenditure is positively related to economic growth. 
As expected, Recurrent Health Expenditure (RCHE) exhibited an insignificant and negative relationship with economic growth. This aligns with the work of Mehrara and Musai (2011), who found a negative result between health finance and economic growth in Iran. Supporting the findings of this study also, Karim (2016) evaluates the economic growth nexus of health expenditure in Nigeria found that health expenditure does not significantly influence economic growth. This is because the part of this expenditure go into the pockets of individual as salaries and wages. This expenditure also gets into the health sector as Out-of-Pocket Health Expenditure, which is $72.2 \%$ in 2015 and reflects low/medium income characteristics of the country. This has also given rise to high percentage in private sector expenditure on health as a share of total health expenditure, which has fluctuated over the years from 79.6 in $2005,79.7 \%$ in 2010 to $73.7 \%$ in 2015 (World Data Atlas). This is, by all standards, very high implying that the public sector could only provide in the respective years $20.4 \%, 20.3 \%, 26.3 \%$ of health services to the people, which in our opinion is very abysmal for a country like Nigeria.

The findings from the study are revealing. The behavior of the variables, as noted earlier, aligns with a priori expectation. The capital expenditure on health (CXHE), which is the most critical variables that should drive the health sector is significantly related with very marginal value of $0.03 \%$ contribution. It is expected given that in 2015 , general government expenditure on health as a share of general government expenditure for Nigeria was $5.3 \%$ (World Data Atlas). This means that $97.7 \%$ of government health expenditure is externally provided. That calls for concern especially in an obvious dwindling health situation of the growing population. The reasons for these disturbing indicators are be far fetch. A good look at the budgetary allocation of $3.5 \%$ of the total budget in the estimated 2018 budget, one would feel so worried with this very low percentage especially when compared with the African Union (AU) "Abuja declaration" of $15 \%$ minimum allocation. Recalling the previous allocations, there have been a consistent reduction from 5.95\% in 2012 (the highest since the Abuja Declaration in 2001) to 4.23\% and $4.16 \%$ in the 2016 and 2017 budget allocations respectively. The World Bank Open Data showed that Nigeria's Total Health Expenditure as \% of GDP was 3.6\% in 2015 and ranked 165 out of 187 . These worrisome indexes aligns with the study's findings. Consequently, the health sector is battling with catalogue of diseases ravaging the citizens. According to Adepoju (2018) the country is struggling with several disease outbreaks including Monkeypox, Measles, and Lassa fever in addition to efforts to end poliomyelitis and tackle the country's noticeable high maternal and child deaths.

\subsection{Recommendations}

From the findings and discussion, the study recommends the following: 
Nigerian government should as a matter of priority increase budgetary allocation to the health sector by $40 \%$ yearly incremental allocation based on the current (2017) provision of $4.16 \%$. This means that by 2021 , Nigeria would have surpassed AU "Abuja Declaration" minimum provision of $15 \%$ by $0.97 \%$.

Conscious, objective and deliberate efforts should be made by the government to give priority to developing health infrastructure and providing quality health services through judicious implementation of approved allocation as recommended. Moral and attitudinal true change is key! This will help in reducing catalogue of health related diseases and improving health status of the citizens, who are the engine of economic growth through their productive activities.

Increased investment in human capital and public health should be encourage and sustained as these increases labour productivity and subsequently generates greater income and economic growth.

\subsection{Conclusion}

The study on Health Finance and Economic Growth in Nigeria and the findings there from is a reflection of global reports and do not speak well of "Giant of Africa" in the $21^{\text {st }}$ century. The distortions associated with each variable in our model are very much open to adjustment especially in the short-run as well as in the long-run. There is clear evidence of inequality in the access to health care services and low income characteristics of the country in view of the high level of Out-of-Pocket Health Expenditure of $77.7 \%, 77.5 \%$ and $72.2 \%$ in 2005,2010 and 2015 respectively. The wide gaps in the various segments of financing the health sector and the effect on the economy, which culminate to the very poor national and global rankings, can be addressed with tangible results. These can be actualized if the recommendations proffered are timely implemented with great focus and will by leadership of the country at national, state and local levels. This is one of the best ways health finance can be used to achieve strong and sustainable economic growth in Nigeria.

\section{REFERENCES}

Adekola, A. I. (2014). Public investment in human capital and economic growth in Nigeria: Analysis on regime shifts. Journal of Economics and Development Studies, 2(2), 213-231. 
Adeoye, Y. M., \& Afolabi, F. O. (2014). Appraising the Role of Educational Management in Initiating and Sustaining a Viable Health Education for National Security in Nigeria Tertiary Institutions. The Social Sciences, 9(2), 102-107.

Adepoju, A., Van Noorloos, F., \& Zoomers, A. (2010). Europe's Migration Agreements with Migrant-Sending Countries in the Global South: A Critical Review. International migration, 48(3), 42-75.

Akinleye, A., Furqan, M., Mukhi, N., Ravella, P., \& Liu, D. (2013). MEK and the inhibitors: from bench to bedside. Journal of hematology \& oncology, 6(1), 27.

Alam, G. M. (2009). The role of science and technology education at network age population for sustainable development of Bangladesh through human resource advancement. Scientific Research and Essays, 4(11), 1260-1270.

Bhatnagar, A., \& George, A. S. (2016). Motivating health workers up to a limit: partial effects of performance-based financing on working environments in Nigeria. Health policy and planning, 31(7), 868-877.

Dauda, R. O. (2010). Role of human capital in economic development: an empirical study of Nigerian case. In Manuscript, Oxford Business and Economics Conference Program.

Devlin, N., \& Hansen, P. (2001). Health care spending and economic output: Granger causality. Applied Economics Letters, 8(8), 561-564.

Frankel, J. A., \& Romer, D. H. (1999). Does trade cause growth?. American economic review, 89(3), 379399.

Giang, D. T., \& Pheng, L. S. (2011). Role of construction in economic development: Review of key concepts in the past 40 years. Habitat international, 35(1), 118-125.

Jakovljevic, M., \& Getzen, T. E. (2016). Growth of global health spending share in low and middle income countries. Frontiers in pharmacology, 7, 21.

Loto, M. A. (2011). Impact of government sectoral expenditure on economic growth. Journal of Economics and international Finance, 3(11), 646-652.

Marques-Deak, A., Cizza, G., Eskandari, F., Torvik, S., Christie, I. C., Sternberg, E. M., \& Phillips, T. M. (2006). Measurement of cytokines in sweat patches and plasma in healthy women: validation in a controlled study. Journal of immunological methods, 315(1-2), 99-109.

Mathur, V. K. (1999). Human capital-based strategy for regional economic development. Economic Development Quarterly, 13(3), 203-216. 
Mayosi, B. M., Lawn, J. E., Van Niekerk, A., Bradshaw, D., Karim, S. S. A., Coovadia, H. M., \& Lancet South Africa team. (2012). Health in South Africa: changes and challenges since 2009. The Lancet, 380(9858), 2029-2043.

Mehrara, M., \& Musai, M. (2011). Granger causality between Health and Economic Growth in oil exporting countries. Interdisciplinary Journal of Research in Business, 1(8), 103-108.

Nawaz, S. (2015). Growth effects of institutions: A disaggregated analysis. Economic Modelling, 45, 118126.

Naylor, M. D., Brooten, D., Campbell, R., Jacobsen, B. S., Mezey, M. D., Pauly, M. V., \& Schwartz, J. S. (1999). Comprehensive discharge planning and home follow-up of hospitalized elders: a randomized clinical trial. Jama, 281(7), 613-620.

Olakunde, B. O. (2012). Public health care financing in Nigeria: Which way forward?. Annals of Nigerian Medicine, 6(1), 4.

Olayemi, S. O. (2012). Human capital investment and industrial productivity in Nigeria. International Journal of Humanities and Social Science, 2(16), 298-307.

Oni, L. B. (2014). Analysis of the growth impact of health expenditure in Nigeria. IOSR Journal of Economics and Finance, 3(1), 77-84.

Onisanwa, I. D. (2014). The impact of health on economic growth in Nigeria. Journal of Economics and Sustainable Development, 5(19), 159-166.

Peacock, A. T. (2004). The growth of public expenditure. In The encyclopedia of public choice (pp. 594597). Springer, Boston, MA.

Torvik, R. (2009). Why do some resource-abundant countries succeed while others do not?. Oxford Review of Economic Policy, 25(2), 241-256.

www.World Bank Open Data

www.World Data Atlas/knoema 